\title{
Contaminated sediment dynamics in peatland headwater catchments
}

DOI:

10.1007/s11368-017-1674-8

\section{Document Version}

Accepted author manuscript

Link to publication record in Manchester Research Explorer

\section{Citation for published version (APA):}

Shuttleworth, E., Clay, G. D., Evans, M. G., Hutchinson, S. M., \& Rothwell, J. J. (2017). Contaminated sediment dynamics in peatland headwater catchments. Journal of Soils and Sediments, 17(11), 2637-2647.

https://doi.org/10.1007/s11368-017-1674-8

\section{Published in:}

Journal of Soils and Sediments

\section{Citing this paper}

Please note that where the full-text provided on Manchester Research Explorer is the Author Accepted Manuscript or Proof version this may differ from the final Published version. If citing, it is advised that you check and use the publisher's definitive version.

\section{General rights}

Copyright and moral rights for the publications made accessible in the Research Explorer are retained by the authors and/or other copyright owners and it is a condition of accessing publications that users recognise and abide by the legal requirements associated with these rights.

\section{Takedown policy}

If you believe that this document breaches copyright please refer to the University of Manchester's Takedown Procedures [http://man.ac.uk/04Y6Bo] or contact uml.scholarlycommunications@manchester.ac.uk providing relevant details, so we can investigate your claim.

\section{OPEN ACCESS}




\section{Journal of Soils and Sediments \\ Contaminated sediment dynamics in peatland headwater catchments \\ --Manuscript Draft--}

Manuscript Number:

Full Title:

Article Type:

Section/Category:

Corresponding Author:
JSSS-D-16-00672R1

Contaminated sediment dynamics in peatland headwater catchments

SI: Transfer of Sediments and Contaminants in Catchments and Rivers

Soils

Emma Shuttleworth

University of Manchester

UNITED KINGDOM

Corresponding Author Secondary Information:

Corresponding Author's Institution:

University of Manchester

Corresponding Author's Secondary Institution:

First Author:

Emma Shuttleworth

First Author Secondary Information:

Order of Authors:

Emma Shuttleworth

Gareth Clay

Martin Evans

Simon Hutchinson

James Rothwell

Order of Authors Secondary Information:

Funding Information:

Abstract:

Response to Reviewers:

Purpose: Despite substantial research into $\mathrm{Pb}$ storage in peatlands, formal description of the mechanisms of contaminated sediment mobilisation is limited. This study explores the controlling factors of contaminated sediment dynamics in an eroding peatland in the Peak District National Park, UK.

Materials and methods: This study uses the $\mathrm{Pb}$ contamination stored near the peat's surface as a fingerprint to trace contaminated sediment dynamics in three severely degraded headwater catchments. A field portable XRF analyser was used across a range of catchment surfaces to examine patterns of contaminant storage and release.

Results and discussion: Lead concentrations varied greatly over a small spatial scale. Erosion is exposing high concentrations of $\mathrm{Pb}$ on interfluve surfaces (up to $1660 \mu \mathrm{g}$ g1 ), and substantial amounts of reworked contaminated material (up to $1010 \mu \mathrm{g} g-1$ ) are stored on other catchment surfaces (gully walls and floors). A variety of factors have been shown to significantly control $\mathrm{Pb}$ release and storage in this environment, including wind action, aspect, and gully depth. Vegetation also plays an important role in retaining sediment-bound heavy metals within contaminated peat catchments.

Conclusions: This study provides the first comprehensive overview of the mechanisms controlling $\mathrm{Pb}$ release and storage in degraded peatlands. Previous assessments of $\mathrm{Pb}$ fluxes may have underestimated contaminant export from severely degraded systems. Wind has also been identified as an as yet unaccounted for vector for heavy metal transport in peatland environments.

Please see separate file 
TRANSFER OF SEDIMENTS AND CONTAMINANTS IN CATCHMENTS AND RIVERS

Contaminated sediment dynamics in peatland headwater catchments

\author{
Emma L. Shuttleworth ${ }^{1} \bullet$ Gareth D. Clay ${ }^{1} \bullet$ Martin G. Evans $^{1} \bullet$ Simon M. Hutchinson ${ }^{2} \bullet$ \\ James J. Rothwell ${ }^{1}$
}

Received: 28 September 2016 / Accepted: 26 January 2017

(c) Springer-Verlag Berlin Heidelberg 2017

Responsible editor: Patrick Byrne

${ }^{1}$ Geography, School of Environment, Education and Development, University of Manchester, Oxford Road, Manchester, M13 9PL, UK

${ }^{2}$ School of Environment and Life Sciences, University of Salford, Salford, M5 4WT, UK

$\square$ Emma L. Shuttleworth

emma.shuttleworth@manchester.ac.uk 


\begin{abstract}
Purpose: Despite substantial research into $\mathrm{Pb}$ storage in peatlands, formal description of the mechanisms of contaminated sediment mobilisation is limited. This study explores the controlling factors of contaminated sediment dynamics in an eroding peatland in the Peak District National Park, UK.

Materials and methods: This study uses the $\mathrm{Pb}$ contamination stored near the peat's surface as a fingerprint to trace contaminated sediment dynamics in three severely degraded headwater catchments. A field portable XRF analyser was used across a range of catchment surfaces to examine patterns of contaminant storage and release.

Results and discussion: Lead concentrations varied greatly over a small spatial scale. Erosion is exposing high concentrations of $\mathrm{Pb}$ on interfluve surfaces (up to $1660 \mu \mathrm{g} \mathrm{g}^{-1}$ ), and substantial amounts of reworked contaminated material (up to $1010 \mu \mathrm{g} \mathrm{g}^{-1}$ ) are stored on other catchment surfaces (gully walls and floors). A variety of factors have been shown to significantly control $\mathrm{Pb}$ release and storage in this environment, including wind action, aspect, and gully depth. Vegetation also plays an important role in retaining sedimentbound heavy metals within contaminated peat catchments.

Conclusions: This study provides the first comprehensive overview of the mechanisms controlling $\mathrm{Pb}$ release and storage in degraded peatlands. Previous assessments of $\mathrm{Pb}$ fluxes may have underestimated contaminant export from severely degraded systems. Wind has also been identified as an as yet unaccounted for vector for heavy metal transport in peatland environments.
\end{abstract}

Key words Blanket peat $\bullet$ Deposition $\bullet$ Erosion $\bullet$ Heavy metals $\bullet$ Vegetation $\bullet$ Wind 


\section{Introduction}

The near-surface layer of peatlands in close proximity to urban and industrial areas can be contaminated with atmospherically deposited heavy metals (Vile et al. 1999; Rothwell et al. 2010a). As such, peatlands can represent significant sinks of anthropogenically derived heavy metals such as lead (Pb) (Shotyk et al. 2000; Farmer et al. 2005; Rothwell et al. 2007a). Many blanket peats in the UK are substantially degraded as a result of climate change, pollution, and mismanagement (Ferguson et al. 1978; Holden et al. 2007; Bonn et al. 2009). Consequently, there is concern that erosion is releasing substantial quantities of $\mathrm{Pb}$ contaminated sediment into the fluvial system (Yang et al. 2002; Shotbolt et al. 2006; Rothwell et al. 2007a, 2008b, 2010b), and that the removal of contaminated surface material is reducing the function of peatlands as a long-term sink for atmospherically deposited contaminants (Rothwell et al. 2008b).

Recent peatland $\mathrm{Pb}$ research has focussed on understanding the processes involved in the release of contaminated sediment. Rothwell et al. (2005, 2007a, 2008b) have shown that peat erosion is releasing substantial amounts of $\mathrm{Pb}$ into the fluvial system in both particulate and dissolved phases. Heavy metals can then be captured in impoundments on rivers such as reservoirs (Shotbolt et al. 2006) and floodplains (Chudaničová et al. 2016), leading to concerns over ecological and human health. Other studies have modelled $\mathrm{Pb}$ release under acidification and drought scenarios (e.g. Lucassen et al. 2002; Tipping et al. 2003). Further modelling (Rothwell et al. 2010b; Shuttleworth et al. 2015) and technical developments (e.g. portable XRF (pXRF), Shuttleworth et al. 2014) have led to an increased understanding of 
the spatial and temporal patterns of $\mathrm{Pb}$ across upland peatlands in the UK.

Near-surface $\mathrm{Pb}$ storage has been shown to be highly heterogeneous due to spatial variability in atmospheric $\mathrm{Pb}$ deposition (Bindler et al. 2004; Farmer et al. 2005; Rothwell et al. 2007a). This can be further complicated by the erosion of surface material from exposed surfaces in degraded areas (Shuttleworth et al. 2015). This complexity presents a significant challenge when modelling catchment $\mathrm{Pb}$ fluxes. Rothwell et al. (2010b) derived a strong relationship between gully depth and sediment-associated lead concentrations, but Shuttleworth et al. (2015) found that this relationship broke down in areas of severely degraded peat where a higher than expected proportion of material derived from the contaminated surface was entering the fluvial system. Shuttleworth (unpublished data) also found that in some headwater catchments suspended sediment $\mathrm{Pb}$ concentrations exceed those stored on interfluve surfaces, indicating that there may be substantial storage of $\mathrm{Pb}$ contaminated sediment elsewhere in the catchment. A deeper understanding of the mechanisms of $\mathrm{Pb}$ release and storage is therefore required to better quantify contaminant export from eroding peat systems.

Rothwell et al. (2007b) proposed that variability in the Pb content of fluvial sediments was likely to be due to differences in catchment erosion processes in degraded upland peatlands. A variety of controls on peatland erosion and sediment dynamics have previously been proposed (Table 1). Peat erosion is negligible below an established plant cover; bare peat, by contrast, is readily erodible (Bragg and Tallis 2001). An exposed peat surface is therefore a prerequisite for erosion to take place. Sediment 'preparation' is often cited as 
an important control on sediment production and mobilisation on bare peat surfaces (e.g. Tallis 1973; Francis 1990; Labadz et al. 1991). Freshly exposed peat is fibrous, cohesive, and resistant to water erosion, while weathering produces a superficial friable layer on bare peat surfaces, which is readily mobilised and rapidly depleted (Evans and Warburton 2007). This loose sediment has a very low density which can be removed from bare peat surfaces by one of three key mechanisms: (i) through the action of running water (e.g. Labadz et al. 1991; Evans et al. 2006); (ii) wind (Tallis 1997; Warburton 2003; Foulds and Warburton 2007a, b); (iii) chemical oxidation (Francis 1990; Waddington and McNeil 2002; Evans and Warburton 2005). Evans and Warburton (2005) and Evans et al. (2006) provide a robust assessment of the full range of peat erosion processes from a single peatland site. However, these studies focussed on constructing sediment budgets and quantifying the catchmentscale export of organic sediment, and do not consider contaminants. To date, there has been no attempt to provide a comprehensive overview of the mechanisms which control $\mathrm{Pb}$ movement including its release and storage in degraded peatlands.

This paper employs the $\mathrm{Pb}$ contamination stored near the peat's surface as a fingerprint to trace contaminated sediment movement and storage in three severely degraded peat headwater catchments. Lead concentrations across different catchment surfaces (interfluves, gully walls, and gully floors) are quantified, and patterns in $\mathrm{Pb}$ concentration are investigated to identify the key controls on $\mathrm{Pb}$-contaminated sediment dynamics.

\section{Methods}




\subsection{Field area}

The Bleaklow Plateau is an area of upland blanket peat that makes up part of the Peak District National Park (PDNP) in the southern Pennines, UK (Fig. 1a). The plateau lies between 500 and $633 \mathrm{~m}$ asl, and is situated between the cities of Manchester and Sheffield which were the heartlands of the English Industrial Revolution. Peat depths of up to $3 \mathrm{~m}$ (Evans and Lindsay 2010a) overlie a sandstone bedrock from the Millstone Grit Series (MGS) (Wolverson-Cope 1976) and fine grained head deposits of weathered MGS shales (Rothwell et al. 2005). Mean monthly temperatures vary between $13.2^{\circ} \mathrm{C}$ (July) and $1.6^{\circ} \mathrm{C}$ (February)

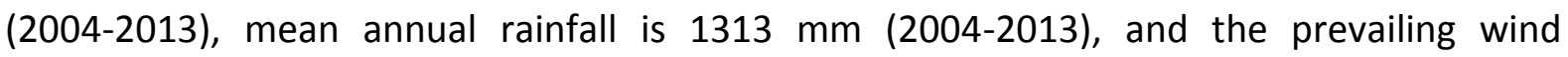
direction is WSW (254 ${ }^{\circ}$ (Clay and Evans 2016). The PDNP supports a range of ecosystem services including tourism, food production, grouse moorland, drinking water and carbon sequestration (Bonn et al. 2009).

The peatlands of the PDNP are amongst the most degraded and contaminated in the world. Anthropogenic and climatic pressures have caused widespread erosion (Bower 1960a, 1960b, 1961; Tallis 1985; Bonn et al. 2009). Peak Pb concentrations of up to $1650 \mu \mathrm{g} \mathrm{g}^{-1}$ can typically be found between 5 and $10 \mathrm{~cm}$ below the peat's surface, surface $\mathrm{Pb}$ concentrations in excess of $300 \mu \mathrm{g} \mathrm{g}^{-1}$ are common, and $\mathrm{Pb}$ contamination is minimal below depths of $30 \mathrm{~cm}$ (Rothwell et al. 2007a, b). Bleaklow has been the focus of a multi-million pound restoration initiative (Shuttleworth et al. 2015), but this study concentrates on three headwater catchments in an actively eroding area of the plateau to the north of Bleaklow Head (Fig. 1b). This area has been purposefully left in its degraded state to act as a baseline for 
comparison with restored areas. Consequently, the field site has been the focus of recent research into carbon release, pollutant dynamics, and peatland restoration (e.g. Clay et al. 2012; Dixon et al. 2014; Cole et al. 2014; Shuttleworth et al. 2014, 2015).

The three headwater catchments are typical of the area, with steep walled gullies with depths varying from around $1 \mathrm{~m}$ at the gully heads to $3-4 \mathrm{~m}$ at the gully mouths. Vegetation cover is sparse and bare peat is prevalent. Any vegetation present on interfluve surfaces is composed of a mixture of low lying shrubs (Calluna vulgaris, Erica tetralix, Vaccinium myrtillus) and cotton grass (Eriophorum spp.) reflecting a mixture of the original pre-gullying vegetated surface and some newly-established vegetation. Vegetation on gully walls and floors is dominated by cotton grass, which is thought to have established on these surfaces post-disturbance (Crowe et al. 2008). A small number of ericaceous shrubs are present on gully walls and appear to have originated at the peat's surface, but have been transported downslope during localised slope failure.

\subsection{Field survey}

Surface $\mathrm{Pb}$ concentrations were measured at $1 \mathrm{~m}$ intervals along four parallel transects (spaced approximately $10 \mathrm{~m}$ ) running perpendicular to the three gullies (Fig. 1b). A total of 188 readings were taken using a handheld Niton XL3t 900 XRF analyser following the method outlined in Shuttleworth et al. (2014). The limit of detection (LOD) for $\mathrm{Pb}$ is $7 \mu \mathrm{g} \mathrm{g}^{-1}$ (Shuttleworth et al. 2014). Where necessary, vegetation was gently removed and the peat's surface was lightly compacted by hand in order to present a smooth flat surface to the XRF 
sensor (c.f. Ridings et al. 2000). There is no commercially available XRF Certified Reference Material (CRM) for heavily contaminated peat so NCS DC73308 (Chinese stream sediment, manufactured by NIST) was used as this has the most appropriate $\mathrm{Pb}$ concentration of the CRMs available to the study. The relative percent difference (RPD) between the concentration in the reference material and the concentration measured by the pXRF was within $10 \%$ for $\mathrm{Pb}$. Samples from the top $1-1.5 \mathrm{~cm}$ of each sampling point were collected using a stainless steel palette knife in order to determine the water content to correct for the dilution effect of the high moisture content of the peat (c.f. Shuttleworth et al. 2014).

\subsection{Data analysis}

\subsubsection{Surface, catchment and vegetation effects}

A general linear model (GLM) approach based on an analysis of variance (ANOVA) was employed to determine the statistical significance of the influence of three factors (catchment, surface type, and vegetation) and their interactions on Pb storage. Firstly, the amount of contamination within each catchment may be influenced by heterogeneous aerial deposition and storage (Bindler et al. 2004; Rothwell et al. 2007a) which would restrict the amount of contaminated sediment available for redistribution on the different surfaces. Secondly, $\mathrm{Pb}$ concentrations on the different catchment surfaces were compared to investigate the relative amounts of contaminated sediment stored on each surface type. Finally, the presence or absence of vegetation was also included, as vegetation and sediment dynamics are closely linked in blanket peats (Evans and Warburton 2005; Evans et 
al. 2006; Shuttleworth et al. 2015).

Initial investigation of the data showed that $\mathrm{Pb}$ storage on northwest (NW) facing gully walls was significantly different to $\mathrm{Pb}$ storage on southeast (SE) facing walls (2-tailed t-test, $\mathrm{p}<$ 0.0001 ) so these were included in the model as two separate surface types. Lead data within each factor were tested for normality (Anderson-Darling) and equality of variance (Levene); any factors that failed were square root transformed. Tukey's pairwise comparison was applied post hoc to assess where the significant differences lie. All relationships were tested at the $95 \%$ level $(p \leq 0.05)$. The magnitude of the effects of each significant factor and interaction were calculated using a generalised $\omega^{2}$ (Olejnik and Algina 2003).

\subsubsection{Directional trends}

The nonparametric Spearman's rank correlation coefficient was employed to test for directional trends in the un-transformed data (Hollander and Wolfe 1973). Pb concentrations were tested against their corresponding easting value as a proxy for wind direction. The effect of gully depth on the pattern of $\mathrm{Pb}$ storage was assessed for both gully walls and gully floors. The pattern of $\mathrm{Pb}$ storage on gully walls was considered by investigating the relationship between $\mathrm{Pb}$ concentration and the depth of the sampling point below the interfluve surface, similar to the method of Rothwell et al. (2010b). This analysis was carried out on individual sections of transect where there was a sampling frequency on gully walls of greater than five; in total five sections could be analysed. The pattern of $\mathrm{Pb}$ storage on gully floors was also considered. The gully depth map developed by 
Evans and Lindsay (2010a) was not of a suitable resolution to derive accurate gully depth values for the gully floor sampling points, so the relationship between $\mathrm{Pb}$ concentrations and distance from the gully head was tested. This is based on the assumption that in headwaters gully depth rapidly increases with distance from gully head (Evans and Lindsay 2010).

\section{Results}

Figure 2 shows $\mathrm{Pb}$ storage on the different catchment surfaces, Table 2 summarises the $\mathrm{Pb}$ concentrations which characterise each of the levels that make up the factors tested by the GLM, and Table 3 summarises the results of the ANOVA. All surfaces store substantial amounts of $\mathrm{Pb}$ contaminated sediment, but this storage is highly variable. Concentrations across the field site range from below the limit of detection to $1660 \mu \mathrm{g} \mathrm{g}^{-1}$, and $\mathrm{Pb}$ contaminated and clean sediment can be found in all catchments and on all surface types. Variation in $\mathrm{Pb}$ concentration is evident both between and within the catchments and surface types; all bar one relative standard deviation (RSD) is in excess of $80 \%$ (Table 2). Interfluve surfaces contain the highest $\mathrm{Pb}$ concentrations (mean $244 \mu \mathrm{g} \mathrm{g}^{-1}$, max $1660 \mu \mathrm{g} \mathrm{g}^{-1}$ ) but there is also considerable $\mathrm{Pb}$ storage on gully floors and walls.

The total explanatory power of the ANOVA model is $27.6 \%$ (Table 3 ). This reflects the complex pattern of $\mathrm{Pb}$ storage displayed in Fig. 2, and is likely to be in part a product of the interference of directional relationships. Despite this, surface type was found to be a significant factor in the ANOVA, explaining $17.2 \%$ of the variation in the data. Post-hoc 
testing shows $\mathrm{Pb}$ storage on NW-facing walls is significantly lower than on SE-facing walls $(p=0.002)$ and interfluve surfaces $(p<0.001)$, but no other significant differences were identified between surface types (Fig. 3b). Catchment is also significant, explaining $3 \%$ of the variation in the data (Table 3); Pb storage in Catchment 1 is significantly lower than that of Catchment 3 ( $p=0.011$; Fig. 3a). The interaction between surface type and vegetation cover was also found to be significant, but vegetation cover alone was not (Table 3). Bare NW-facing walls contain significantly lower $\mathrm{Pb}$ concentrations than all other bare surfaces ( $p$ $<0.001)$, and vegetated interfluve surfaces $(p<0.001)$ and vegetated SE-facing walls $(p=$ 0.005). Vegetated gully floors also contain significantly lower $\mathrm{Pb}$ concentration than vegetated interfluve surfaces $(p=0.008)$.

Although there is no statistically significant difference in $\mathrm{Pb}$ storage between bare and vegetated areas on individual surfaces, there are some interesting relationships which should be noted. Lead concentrations tend to be higher under vegetation on interfluve surfaces and on NW-facing gully walls; mean Pb storage on bare interfluve surfaces is $67 \%$ of the mean vegetated value, while mean Pb storage on bare NW-facing walls is only $34 \%$ of the mean concentration found under vegetation (Table $4 ;$ Fig. $3 c$ ). In contrast, $\mathrm{Pb}$ concentrations are substantially lower under vegetation on gully floors than on bare areas. Mean $\mathrm{Pb}$ storage on bare gully floors is almost 3 times higher than the mean vegetated concentration (Table 4; Fig. 3c). This indicates that vegetated and bare areas affect contaminant storage in different ways on the different surface types, and may explain why the GLM did not identify vegetation as a significant factor. 
When considering the relationship between $\mathrm{Pb}$ storage and gully depth, there is a significant negative relationship between Pb storage and distance from gully head on gully floors ( $\rho=-$ $0.359, p=0.022,2$ tailed) i.e. higher $\mathrm{Pb}$ concentrations are found near gully heads than gully mouths. Out of the five sections of gully wall transect, four did not show any relationship between $\mathrm{Pb}$ concentration and depth of sampling (all $\mathrm{p}>0.05$ ). The fifth section did produce a statistically significant result $(\rho=1)$; however, this was in the opposite direction than expected i.e. higher $\mathrm{Pb}$ concentrations were found at the base of the gully wall than near the top.

There was no correlation between easting (as a proxy for wind direction) and $\mathrm{Pb}$ concentration on interfluve surfaces ( $\rho=-0.116, p=0.313,2$ tailed).

\section{Discussion}

\subsection{Patterns of contaminant storage}

High concentrations of $\mathrm{Pb}$ were found in the study catchments. The highest $\mathrm{Pb}$ concentrations measured in this study $\left(1660 \mu \mathrm{g} \mathrm{g}{ }^{-1}\right)$ are comparable to $\mathrm{Pb}$ concentrations found in other studies in the southern Pennines (e.g. $1647 \mu \mathrm{g} \mathrm{g}^{-1}$, Rothwell et al. 2007a), and are similar to some of the highest values recorded elsewhere in the world (e.g. $1527 \mu \mathrm{g} \mathrm{g}^{-1}$ in Gola di Lago, Switzerland: Shotyk et al. 2000; $1650 \mu \mathrm{g} \mathrm{g} \mathrm{g}^{-1}$ in Fennoscandia tundra in Russia: Zhulidov et al. 1997). Lead storage varied between the three catchments with Catchment 1 containing significantly lower $\mathrm{Pb}$ concentrations than the other two catchments (Fig. 3a). This is to be expected, given that the near-surface record of $\mathrm{Pb}$ deposition in the southern 
Pennines can vary by several orders of magnitude both horizontally and vertically over relatively short distances (Rothwell et al. 2007a). This variability could be due to a combination of factors including: differences in peat accumulation rates (e.g. Mighall et al. 2002), spatial heterogeneity in atmospheric deposition (e.g. Norton et al. 1997), spatial and temporal variation in plant community (e.g. Bindler et al. 2004), varying rates of decomposition (Biester et al. 2003) and removal of material by erosion (Shuttleworth et al. 2015).

There are some surprising similarities in the magnitude of $\mathrm{Pb}$ storage on the different catchment surfaces. Freshly exposed material on gully walls and floors should be relatively 'clean' compared to the contaminated near-surface material, but Pb concentrations on SEfacing gully walls and gully floors are similar to the levels found on the surface of interfluves (Table 2) indicating that these are sites of substantial deposition and storage of reworked contaminated material. The maximum $\mathrm{Pb}$ concentrations found on these surfaces ( 555 and $1010 \mu \mathrm{g} \mathrm{g}^{-1}$ ) exceed many previously reported maximum near-surface $\mathrm{Pb}$ concentrations found in peatlands around the world (e.g. $479 \mu \mathrm{g} \mathrm{g}^{-1}$ in Bozi Dar, Czech Republic: Vile et al. 2000; $400 \mu \mathrm{g} \mathrm{g}^{-1}$ in Lochnagar, Scotland: Yang et al. 2001). Rothwell et al. (2007b) found that re-deposited fluvial sediment (on floodplains, fans, and trash-lines) elsewhere in the Peak District contained $40-66 \mu \mathrm{g} \mathrm{g}^{-1} \mathrm{~Pb}$, but concentrations of these re-worked sediments were one or two orders of magnitude lower than those stored near the peat's surface ( $1200 \mu \mathrm{g}$ $\left.\mathrm{g}^{-1}\right)$. The high $\mathrm{Pb}$ concentrations recorded on gully floors and SE-facing gully walls in this study greatly exceed those recorded in reworked sediment by Rothwell et al. (2007b). NWfacing gully walls also store some $\mathrm{Pb}$, but they are the 'cleanest' of the four surface types, 
containing significantly lower $\mathrm{Pb}$ concentrations than the other three surfaces (Table 2 ). The differences in $\mathrm{Pb}$ storage between NW- and SE-facing gully walls suggests that these surfaces may be subject to different processes of deposition and removal.

\subsection{Controls on contaminant storage}

The distribution of $\mathrm{Pb}$ within the catchments is clearly complex, but the statistical analyses have highlighted several factors that influence contaminant storage including vegetation cover, aspect, and depth of gully.

\subsubsection{Vegetation cover}

The presence of vegetation has been shown to greatly influence sediment storage in peatlands (Tallis and Yalden 1983; Evans and Warburton 2005; Evans et al. 2006; Shuttleworth et al. 2015), and although vegetation cover alone was not found to control Pb storage in this study (mean $\mathrm{Pb}$ storage on all bare and vegetated surfaces only differs by 9 $\mu \mathrm{g}^{-1}-$ Table 4), the interaction between surface type and vegetation cover is significant (Table 3). The lowest Pb concentrations overall are found on bare NW-facing gully walls and vegetated gully floors, while the highest concentrations are found on vegetated interfluve surfaces and bare gully floors (Fig. 3c; Table 4). Vegetation cover does not contribute to any statistically significant differences in $\mathrm{Pb}$ storage on individual surface types. However, this is likely due to the high variability in $\mathrm{Pb}$ values recorded on each surface (Table 2), and there are some noticeable differences in mean $\mathrm{Pb}$ storage on bare and vegetated surfaces on 
three of the four surface types (Table 4; Fig. 3c). Higher mean $\mathrm{Pb}$ concentrations are found under vegetation than on bare areas on NW-facing gully walls and interfluve surfaces, while the opposite relationship is evident on gully floors, where mean $\mathrm{Pb}$ storage is highest on bare areas (Table 4; Fig. 3c). This indicates that the presence or absence of vegetation does not have a consistent effect on $\mathrm{Pb}$ storage on the different surface types.

\subsubsection{Interfluve surfaces}

The observed differences in $\mathrm{Pb}$ storage on vegetated and bare interfluve surfaces in the study catchments are likely a product of differing rates of surface lowering. Shuttleworth et al. (2015) found that there is relatively little variation in $\mathrm{Pb}$ concentrations across the surface of intact areas of peatland $\left(290-400 \mu \mathrm{g} \mathrm{g}^{-1}\right)$, while $\mathrm{Pb}$ concentrations on interfluves in degraded areas range from 10's to 1000's $\mu \mathrm{g} \mathrm{g}^{-1}$. Exposed peat is highly susceptible to erosion (Tallis 1997; Evans and Warburton 2007) and Shuttleworth et al. (2015) propose that varying rates of surface erosion in degraded areas expose different stages of the $\mathrm{Pb}$ deposition profile at the peat's surface. Therefore, bare areas on interfluves, being vulnerable to erosive processes, will have been stripped of some (and at some sampling sites, all) of the contaminated layer, resulting in surface $\mathrm{Pb}$ concentrations which range from below the pXRF limit of detection to $1050 \mu \mathrm{g} \mathrm{g}^{-1}$ (Table 2). Vegetation inhibits surface recession so any vegetation present on interfluves will have protected the underlying peat from erosion, preserving the contaminated layer below. 


\subsubsection{Gully walls}

In the Bleaklow area, the record of atmospheric $\mathrm{Pb}$ deposition is limited to the upper $30 \mathrm{~cm}$ of the peat profile (Rothwell et al. 2007a, b). When gully walls are cleared of superficial friable material, $\mathrm{Pb}$ concentrations are negligible (Shuttleworth et al. 2015), so any $\mathrm{Pb}$ enriched material found on gully walls is interpreted to be reworked sediment derived from the near-surface contaminated layer. Lead storage is considerably higher under vegetation on NW-facing walls than on bare areas. This is similar to the observations of $\mathrm{Pb}$ storage on interfluves, but the vegetation on these gully walls affects $\mathrm{Pb}$ storage differently as there is no in-situ contaminated surface to protect. Rather, vegetation intercepts contaminated peat particles which have been mobilised from the peat's surface as they move down the gully walls (Evans and Warburton 2005; Rothwell et al. 2010b) and then protect this redeposited sediment from subsequent erosion. Any contaminated sediment deposited on bare walls is vulnerable to weathering and is easily remobilised, leading to a relative enrichment of $\mathrm{Pb}$ contamination under gully wall vegetation.

No such relationship is evident on SE-facing gully walls where $\mathrm{Pb}$ concentrations are similar on bare and vegetated surfaces, providing further evidence that NW- and SE-facing gully walls may be subject to different processes of deposition and sediment removal.

\subsubsection{Gully floors}

Vegetated gully floors and floodplains have been shown to be important areas of sediment deposition in peatlands (Evans et al. 2005; Rothwell et al. 2007b), and gully floor vegetation 
is often cited as pivotal in reducing connectivity between eroding surfaces and the fluvial system (e.g. Evans and Warburton 2005; Crowe et al. 2008; Molina et al. 2009). It is therefore surprising that mean $\mathrm{Pb}$ concentrations are three times higher on bare peat than on vegetated surfaces, indicating greater storage of contaminated sediment on bare surfaces. However, Evans and Warburton (2005) note that sediment is not efficiently transported across vegetated alluvial fans, indicating sediment deposition may be limited to the upstream extremity of vegetated surfaces. Thus, contaminated sediment may simply not have reached the vegetated sampling locations on gully floors. Figure 4 shows freshly deposited peat building up behind tussocks of Eriophorum spp. (cotton grass) on the floor of Catchment 2, suggesting that vegetation on gully floors may be encouraging upstream deposition in a similar manner to gully blocks which are used to restrict the flow of water and sediment in peatland restoration initiatives (Evans et al. 2005). Bare areas of peat on gully floors therefore represent significant deposition of reworked material derived from the contaminated surface layer.

\subsubsection{Aspect}

Lead storage is significantly higher on SE-facing walls than on NW-facing walls (Fig. 2; Table 2 ), indicating that aspect plays an important role in determining the mechanisms behind sediment dynamics on gully walls in eroding peatlands. The NW-facing gully walls will be more prone to disturbance by frost heave and needle ice formation which would destroy the structure of the surficial peat (Luoto and Seppälä 2000) producing a fluffy loose texture 
that is easily dislodged and transported. Francis (1990) notes that frost heave preferentially affects previously loosened peat, so any redeposited contaminated sediment on NW-facing gully walls would have been particularly prone to frost action and easily removed, leading to lower $\mathrm{Pb}$ storage. Birnie (1993) also reported maximum erosion on northerly aspects suggesting that greater frost frequency was an important factor.

Evans and Warburton (2007) cite running water at the dominant mechanism in mobilising sediment on peatland gully walls. However, NW-facing gully walls in this study will also be relatively more exposed to the prevailing wind than the SE-facing walls, which may also contribute to the difference in $\mathrm{Pb}$ storage on these two surfaces. Aeolian processes have received relatively little attention in the study of peatland erosion, but wind has been shown to be a significant geomorphic process in peatlands in Finland (Seppälä 2001) and Canada (Cummings and Pollard 1990), and Evans and Warburton (2007) note that wind-driven volumetric losses from UK upland peatlands are comparable to agricultural soil losses. The fact that maximum wind-driven UK peatland erosion has been shown to occur on SSW to WNW aspects (Evans and Warburton 2007) would suggest that the differences in Pb storage on the downwind facing gully walls could be driven by exposure to wind.

\subsubsection{Gully depth}

Lead concentrations in gully floor sediments decrease with distance from the gully head, supporting the concept that clean peat makes up a greater proportion of sediment with distance downstream. As gullies deepen, relatively uncontaminated 'clean' peat represents 
a larger proportion of the exposed gully wall. The surface-derived $\mathrm{Pb}$ signal becomes progressively diluted as contaminated and clean particulates mix (Rothwell et al. 2010b).

Despite the evidence from gully floors that the proportion of clean to contaminated sediment increases with gully depth, there is no relationship between gully depth and $\mathrm{Pb}$ storage on gully walls. This is similar to the findings of Shuttleworth et al. (2015) which also did not show any relationship between gully depth and $\mathrm{Pb}$ contaminated suspended sediment. Rothwell et al. (2010b) derived the gully depth-sediment associated $\mathrm{Pb}$ relationship in catchments where interfluves were well vegetated, so any $\mathrm{Pb}$ would only have been sourced from the contaminated layer exposed at the top of gully walls. In our study catchments, no such relationship is evident due to the prevalence of bare interfluve surfaces, releasing large volumes of contaminated material (Shuttleworth et al. 2015), masking any effect of an increasing pool of 'clean' peat as gullies deepen.

\subsection{Implications for management and future research}

Patterns of contaminant storage are consistent with sediment redistribution by both wind and water erosion processes mediated by the presence of vegetation. This adds to the growing body of evidence that re-vegetation is a key component of peatland restoration schemes (e.g. Anderson et al. 2009; Worrall et al. 2011; Shuttleworth et al. 2015).

The observation that wind erosion is a potentially significant vector for contaminated sediment transport highlights a $\mathrm{Pb}$ fraction that is as yet unaccounted for in estimates of peatland $\mathrm{Pb}$ budgets. Fine metal-laden airborne particulates have been shown to affect 
human respiratory health in urban environments (e.g. Fernandez Espinosa et al. 2002; Voutsa and Samara 2002), where sediment associated Pb contamination is not as severe as that found in the near-surface peats of the Peak District. Consequently, the airborne component of the $\mathrm{Pb}$ budget in eroded peatlands could also be important in toxicological terms, given the large number of people that visit the Peak District (in excess of 10 million tourist-days per year; Global Tourism Solutions 2009).

\section{Conclusions}

The legacy of atmospheric $\mathrm{Pb}$ deposition stored near the peat's surface has been successfully employed as a fingerprint to trace contaminated sediment movement and storage in degraded peat headwater catchments. High $\mathrm{Pb}$ concentrations are, as expected, associated with un-eroded peat surfaces which preserve the record of industrial pollution at the sites. High $\mathrm{Pb}$ concentrations are also observed in areas of sediment deposition indicating that legacy $\mathrm{Pb}$ pollution is mobile and reworked in this eroding peatland system. Previous assessments of $\mathrm{Pb}$ fluxes may have underestimated contaminant export from severely degraded systems such as these, and wind has also been identified as an unaccounted for vector for heavy metal transport in peatland environments. Vegetation plays a key role in protecting and trapping contaminated sediment, reinforcing the importance of re-vegetation in the restoration and management of these degraded systems.

Acknowledgements We would like to thank The University of Manchester for the provision 
of a Graduate Teaching Studentship (to E. L. Shuttleworth) and for funding for analytical costs. We are grateful to The National Trust and United Utilities for allowing work to be carried out at the study sites. Thanks also go to Jack Dods and loanna Tantanasi for their help in the field. We also thank two anonymous reviewers for their helpful comments.

\section{References}

Anderson P, Buckler M, Walker J (2009) Moorland restoration: potential and progress. Pages 432-447. In: Bonn A, Allott T, Hubacek H, Stewart J (eds) Drivers of environmental change in uplands. Routledge, Abingdon, United Kingdom

Biester H, Martinez Cortizaz A, Birkenstock S, Kilian R (2003) Effect of peat decomposition and mass loss on historic mercury records in peat bogs from Patagonia. Environ Sci Technol 37:32-39

Bindler R, Klarqvist M, Klaminder J, Forster J (2004) Does within-bog spatial variability of mercury and lead constrain reconstructions of absolute deposition rates from single peat records? The example of Store Mosse, Sweden. Global Biogeochem Cy 18(3):GB3020

Birnie RV (1993) Erosion rates on bare peat surfaces in Shetland. Scot Geogr Mag 109(1):1217

Bonn A, Allott TEH, Hubacek K, Stewart J (2009) Drivers of Environmental Change in Uplands. Abingdon, Oxon, Routledge 
Bonn A, Allott TEH, Evans MG, Joosten H, Stoneman R (eds) (2016) Peatland Restoration and Ecosystem Services: Science, Policy and Practice. Cambridge University Press, Cambridge

Bower MM (1960a) Peat erosion in the Pennines. Adv Sci 64:323-331

Bower MM (1960b) The erosion of blanket peat in the Southern Pennines. East Midland Geogr 2:22-33

Bower MM (1961) The distribution of erosion in blanket peat bogs in the Pennines. T I Brit Geogr 29:17-30

Bragg OM, Tallis JH (2001) The sensitivity of peat-covered upland landscapes. Catena 42(24):345-360

Chudaničová M, Hutchinson SM, Hradecký J, Sedláček J (2016) Environmental magnetism as a dating proxy for recent overbank sediments of (peri-)industrial regions in the Czech Republic and UK. Catena 142:21-35

Clay GD, Evans MG (2016) Ten-year meteorological record for an upland research catchment, near the summit of Snake Pass in the Peak District, UK. Weather

Clay GD, Dixon S, Evans MG, Rowson JG, Worrall F (2012) Carbon dioxide fluxes and DOC concentrations of eroding blanket peat gullies. Earth Surf Proc Land 37:562-571

Cole B, McMorrow J, Evans MG (2014) Empirical modelling of vegetation abundance from airborne hyperspectral data for upland peatland restoration monitoring. Rem Sens 


\section{6:716-739}

Crowe SK, Evans MG, Allott TEH (2008) Geomorphological controls on the re-vegetation of erosion gullies in blanket peat: implications for bog restoration. Mires Peat 3:1-14

Cummings CE, Pollard WH (1990) Cryogenetic characterization of peat and mineral-cored palsas in Schefferville area, Quebec. Coll Nord 54:95-102

Dixon S, Qassim S, Rowson J, Worrall F, Evans MG, Boothroyd I, Bonn A (2014) Restoration effects on water table depths and $\mathrm{CO} 2$ fluxes from climatically marginal blanket bog. Biogeochemistry 118(1):159-176

Evans M, Lindsay J (2010a) High resolution quantification of gully erosion in upland peatlands at the landscape scale. Earth Surf Proc Land 35(8):876-886

Evans M, Warburton J (2005) Sediment budget for an eroding peat-moorland catchment in northern England. Earth Surf Proc Land 30(5):557-577

Evans MG, Warburton J (2007) Geomorphology of Upland Peat. Blackwell, Oxford, 262 pp

Evans MG, Allott TEH, Holden J, Flitcroft C, Bonn A (2005) Understanding gully blocking in deep peat. Moors for the Future Report No. 4, Castleton, Derbyshire

Evans MG, Warburton J, Yang J (2006) Sediment budgets for eroding blanket peat catchments: Global and local implications of upland organic sediment budgets Geomorphology 79(1):45-57

Farmer JG, Graham MC, Bacon JR, Dunn SM, Vinogradoff SI, MacKenzie AB (2005) Isotopic characterisation of the historical lead deposition record at Glensaugh, an organic-rich, 
upland catchment in rural NE Scotland. Sci Total Environ 346(1-3):121-137

Ferguson P, Lee JA, Bell JNB (1978) Effects of sulfur pollutants on growth of sphagnum species. Environ Pollut 16(2):151-162

Fernández Espinosa AJ, Rodríguez MR, Barragán de la Rosa FJ, Jiménez Sánchez JC (2002) A chemical speciation of trace metals for fine urban particles Atmos Environ 36(5):773780

Foulds SA, Warburton J (2007a) Wind erosion of blanket peat during a short period of surface desiccation (North Pennines, Northern England). Earth Surf Proc Land 32(3):481-488

Foulds SA, Warburton J (2007b) Significance of wind-driven rain (wind-splash) in the erosion of blanket peat. Geomorphology 83(1-2):183-192

Francis IS (1990) Blanket peat erosion in a mid-wales catchment during 2 drought years. Earth Surf Proc Land 15(5):445-456

Global Tourism Solutions (2009) Peak District National Park and Influence Area, STEAM Report 2009. Available at http://www.peakdistrict.gov.uk/ data/assets/pdf file/0018/321642/STEAM-2009.pdf Last accessed 31 August 2016

Holden J, Burt TP (2002b) Infiltration, runoff and sediment production in blanket peat catchments: implications of field rainfall simulation experiments. Hydrol Process 16(13):2537-2557 
Holden J, Shotbolt L, Bonn A, Burt, TP, Chapman PJ, Dougill AJ, Fraser EDG, Hubacek K, Irvine B, Kirkby MJ, Reed MS, Prell C, Stagl S, Stringer LC, Turner A, Worrall F (2007) Environmental change in moorland landscapes. Earth-Sci Rev 82(1-2):75-100

Hollander M, Wolfe DA (1973) Nonparametric Statistical Methods. John Wiley \& Sons, New York

Labadz JC, Burt TP, Potter AWR (1991) Sediment yield and delivery in the blanket peat moorlands of the southern Pennines. Earth Surf Proc Land 16(3):255-271

Lucassen ECHET, Smolders AJP, Roelofs JGM (2002) Potential sensitivity of mires to drought, acidification and mobilisation of heavy metals: the sediment $\mathrm{S} /(\mathrm{Ca}+\mathrm{Mg})$ ratio as a diagnostic tool. Environ Pollut 120:635-646

Luoto M, Seppala M (2000) Summit peats ('peat cakes') on the fells of Finnish Lapland: continental fragments of blanket mires? Holocene 10(2):229-241

Mighall TM, Grattan JP, Timberlake S, Lees JA, Forsyth S (2002) An atmospheric pollution history for lead-zinc mining from the Ystwyth Valley, Dyfed, mid-Wales, UK as recorded by an upland blanket peat. Geochem-Explor Env A 2:175-184

Molina A, Govers G, Cisneros F, Vanacker V (2009) Vegetation and topographic controls on sediment deposition and storage on gully beds in a degraded mountain area. Earth Surf Proc Land 34(6):755-767

Norton SA, Evans GC, Kahl JS (1997) Comparison of $\mathrm{Hg}$ and $\mathrm{Pb}$ fluxes to hummocks and hollows of ombrotrophic Big Heath Bog and to Nearby Sargent Mt. Pond, Maine, USA. 
Water Air Soil Poll 100:271-288

Olejnik S, Algina J (2003) Generalized eta and omega squared statistics: Measures of effect size for some common research designs. Psychol Methods 8(4):434-447

Ridings M, Shorter AJ, Smith JB (2000) Strategies for the investigation of contaminated sites using field portable X-ray fluorescence (FPXRF) techniques. Commun Soil Sci Plan 31(1114):1785-1790

Rothwell JJ, Robinson SG, Evans MG, Yang J, Allott TEH (2005) Heavy metal release by peat erosion in the Peak District, southern Pennines, UK. Hydrol Process 19(15):2973-2989

Rothwell JJ, Evans MG, Lindsay JB, Allott TEH (2007a) Scale-dependent spatial variability in peatland lead pollution in the southern Pennines, UK. Environ Pollut 145:111-120

Rothwell JJ, Evans MG, Allott TEH (2007b) Lead contamination of fluvial sediments in an eroding blanket peat catchment. Appl Geochem 22(2):446-459

Rothwell JJ, Taylor KG, Chenery SRN, Cundy AB, Evans MG, Allott TEH (2010a) Storage and behavior of $\mathrm{As}, \mathrm{Sb}, \mathrm{Pb}$, and $\mathrm{Cu}$ in ombrotrophic peat bogs under contrasting water table conditions. Environ Sci Technol 44(22):8497-8502

Rothwell JJ, Lindsay JB, Evans MG, Allott THE (2010b) Modelling suspended sediment lead concentrations in contaminated peatland catchments using digital terrain analysis. Ecol Eng 36(5):623-630

Rutherford A (2001) Introducing ANOVA and ANCOVA: a GLM Approach. Sage, London

Seppälä M (2001) Strong deflation on palsas in Finnish Lapland. Trans Jpn Geomorphol U 
Shuttleworth EL, Evans MG, Hutchinson SM, Rothwell JJ (2014) Assessment of lead contamination in peatlands using field portable XRF. Water Air Soil Poll 225:1844

Shuttleworth EL, Evans MG, Hutchinson SM, Rothwell JJ (2015) Peatland restoration: controls on sediment production and reductions in carbon and pollutant export. Earth Surf Proc Land 40(4):459-472

Shotbolt L, Hutchinson S, Thomas A (2006) Sediment stratigraphy and heavy metal fluxes to reservoirs in the Southern Pennine Uplands, UK. J Paleolimnol 35:305-322

Shotyk W, Blaser P, Grunig A, Cheburkin AK (2000). A new approach for quantifying cumulative, anthropogenic, atmospheric lead deposition using peal cores from bogs: $\mathrm{Pb}$ in eight Swiss peat bog profiles. Sci Total Environ 249(1-3):281-295

Tallis JH (1973) Studies on Southern Pennine peats .5. Direct observations on peat erosion and peat hydrology at Featherbed Moss, Derbyshire. J Ecol 61(1):1-22

Tallis JH (1985) Mass movement and erosion of a southern Pennine blanket peat. J Ecol 73(1) 283-315

Tallis JH (1997) Peat erosion in the Pennines: The badlands of Britain. Biologist 44:277-279

Tallis JH, Yalden DW (1983) Peak District moorland restoration project phase II report: Revegetation trials. Peak Park Joint Planning Board, Bakewell

Tipping E, Smith EJ, Lawlor AJ, Hughes S, Stevens PA (2003) Predicting the release of metals from ombrotrophic peat due to drought-induced acidification. Environ Pollut 
Vile MA, Wieder RK, Novak M (1999) Mobility of $\mathrm{Pb}$ in Sphagnum-derived peat. Biogeochemistry 45(1):35-52

Vile MA, Wieder RK, Novak M (2000) 200 years of Pb deposition throughout the Czech Republic: Patterns and sources. Environ Sci Technol 34(1):12-21

Voutsa D, Samara C (2002) Labile and bioaccessible fractions of heavy metals in the airborne particulate matter from urban and industrial areas Atmos Environ 36(22):3583-3590

Waddington JM, McNeil P (2002) Peat oxidation in an abandoned cutover peatland. Can J Soil Sci 82:279-286

Warburton J (2003) Wind-splash erosion of bare peat on UK upland moorlands. Catena 52(34):191-207

Warburton J, Holden J, Mills AJ (2004) Hydrological controls of surficial mass movements in peat. Earth-Sci Rev 67(1-2):139-156

Wolverson-Cope F (1976) Geology Explained in the Peak District. David and Charles, Devon

Worrall F, Rowson JG, Evans MG, Pawson R, Daniels S, Bonn A (2011) Carbon fluxes from eroding peatlands - the carbon benefit of revegetation following wildfire. Earth Surface Proc Land 36:1487-1498

Yang H, Rose NL, Boyle JF, Battarbee RW (2001) Storage and distribution of trace metals and spheroidal carbonaceous particles (SCPs) from atmospheric deposition in the catchment peats of Lochnagar, Scotland. Environ Pollut 115(2):231-238 
Yang H, Rose NL, Battarbee RW, Boyle JF (2002) Mercury and lead budgets for Lochnagar, a Scottish mountain lake and its catchment. Environ Sci Technol 36(7):1383-1388

Zhulidov AV, Headley JV, Robarts RD, Nikanorov AM, Ischenko AA, Champ MA (1997) Concentrations of $\mathrm{Cd}, \mathrm{Pb}, \mathrm{Zn}$, and $\mathrm{Cu}$ in contaminated wetlands of the Russian Arctic. Mar Pollut Bull 35 (7-12):252-259 


\section{Figure captions}

Fig. 1 Location of the study site. (a) The Bleaklow Plateau in relation to the cities of Manchester and Sheffield. The red star denotes the gullied field area, just north of the Bleaklow summit. The blue star denotes the location of the automatic weather station. (b) View down Catchment 2 (looking NE), showing transect markers running right to left across the photo. Transect markers are spaced at $2 \mathrm{~m}$ intervals

Fig. 2 (a) Schematic depicting mean lead concentrations measured along the four transects on the different catchment surface types (figure not to scale); (b) Interval plot (mean $\pm 95 \%$ C.I.) of lead concentrations grouped by surface type

Fig. 3 Interval plots for factors and interactions which produced significant differences when comparing lead storage based on ANOVA depicting $95 \%$ confidence intervals for the means. Note: the $\mathrm{y}$-axis represents square-root transformed $\mathrm{Pb}$ values

Fig. 4 Freshly deposited peat accumulating behind tussocks of Eriophorum on the floor of Catchment 2 
Fiqure 1

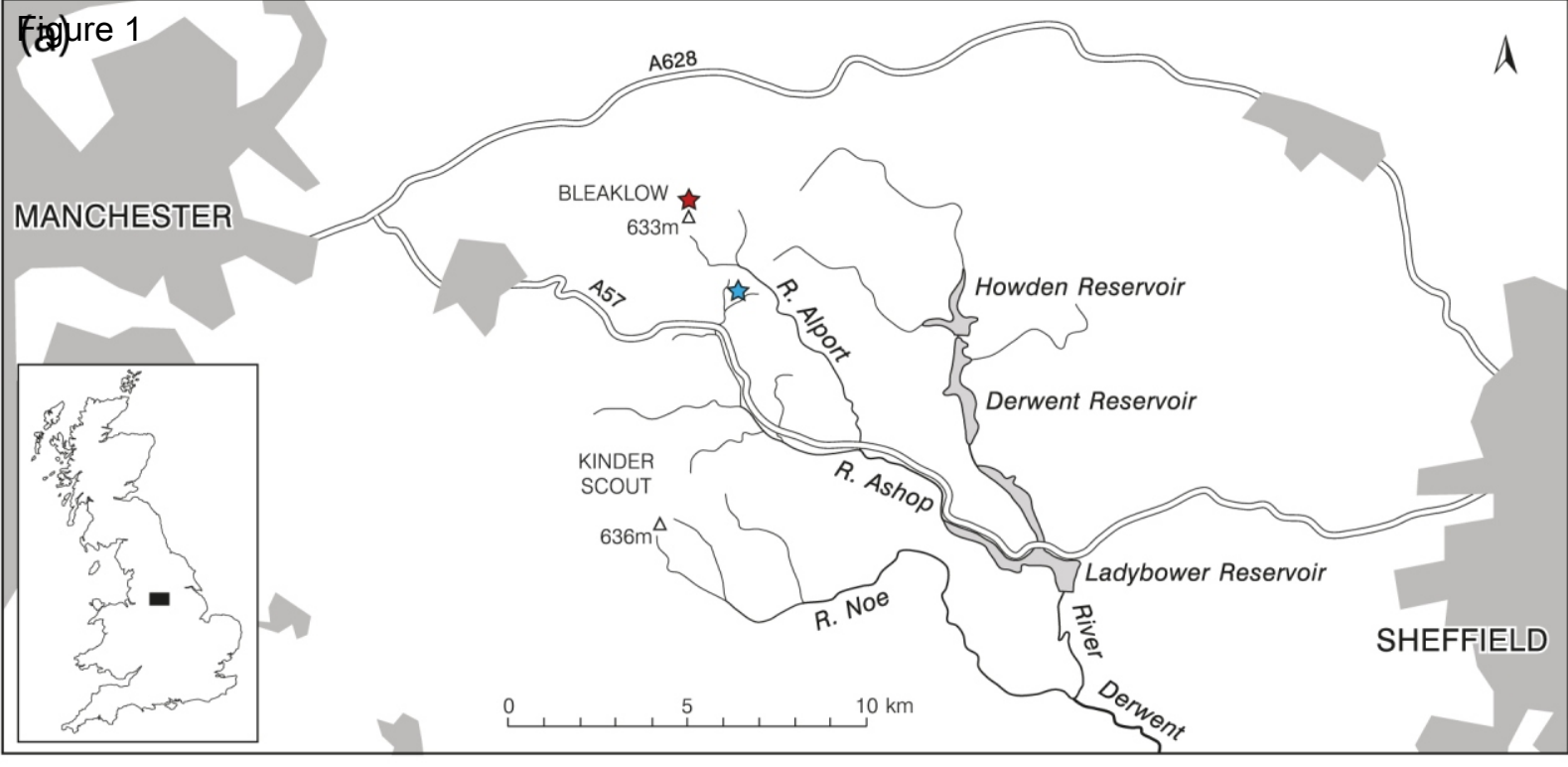

(b)

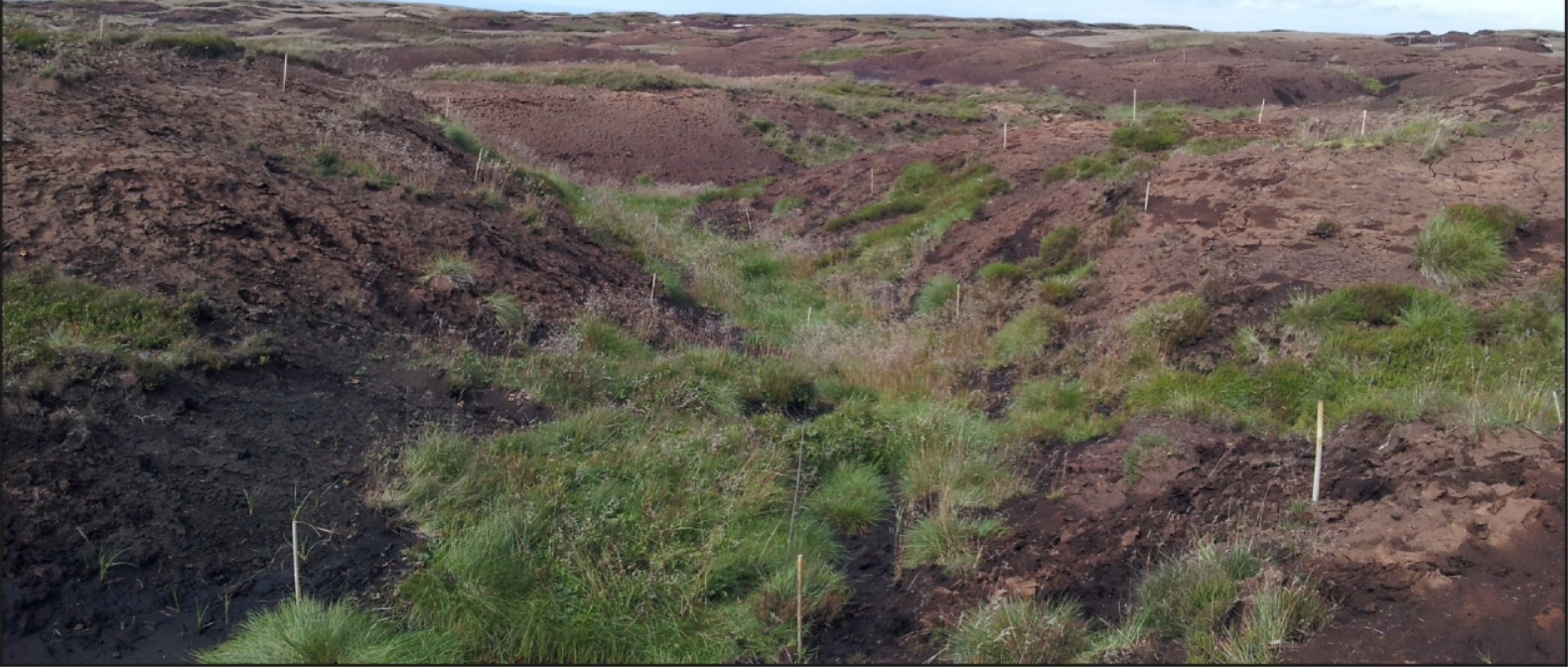


(a)

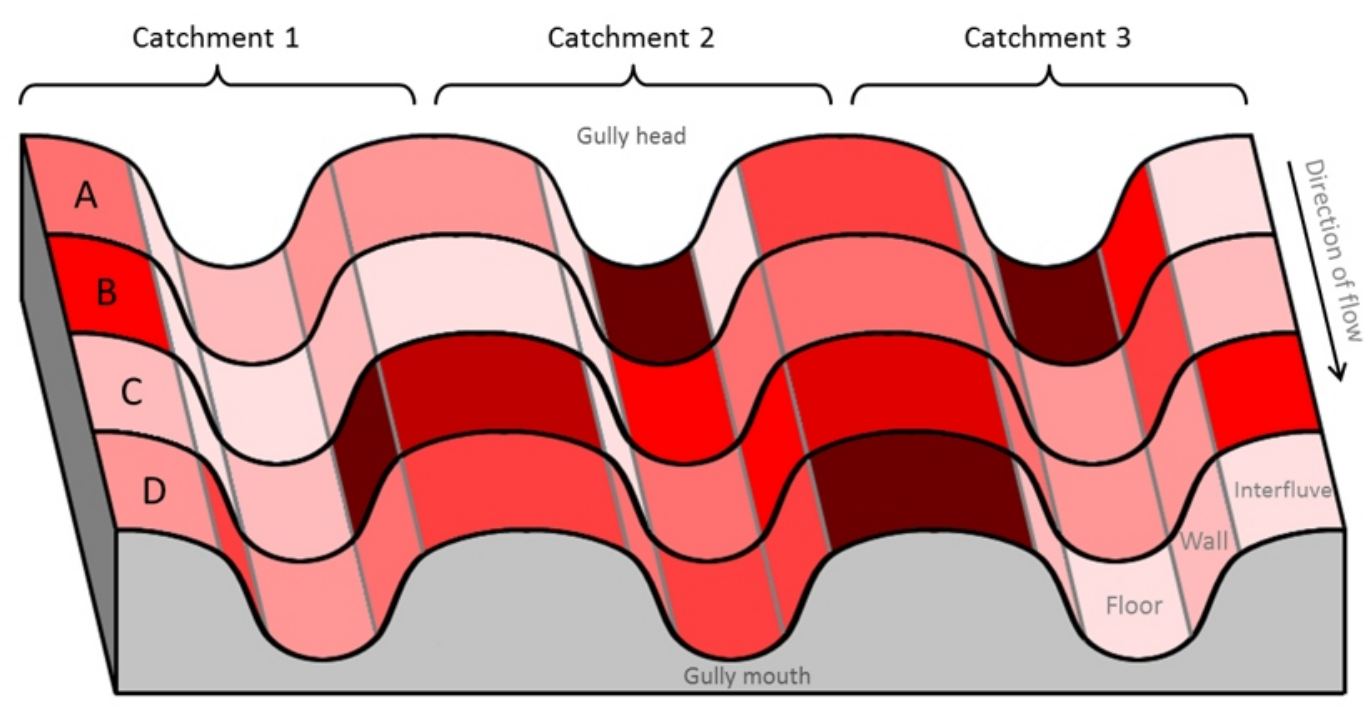

Mean $\mathrm{Pb}\left(\mu \mathrm{g} \mathrm{g}^{-1}\right)$

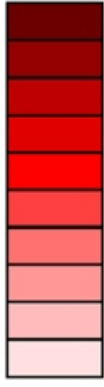

400 - 500

400 - 450

350 - 400

300 - 350

250 - 300

200 - 250

$150-200$

$100-150$

50 - 100

0- 50

(b)

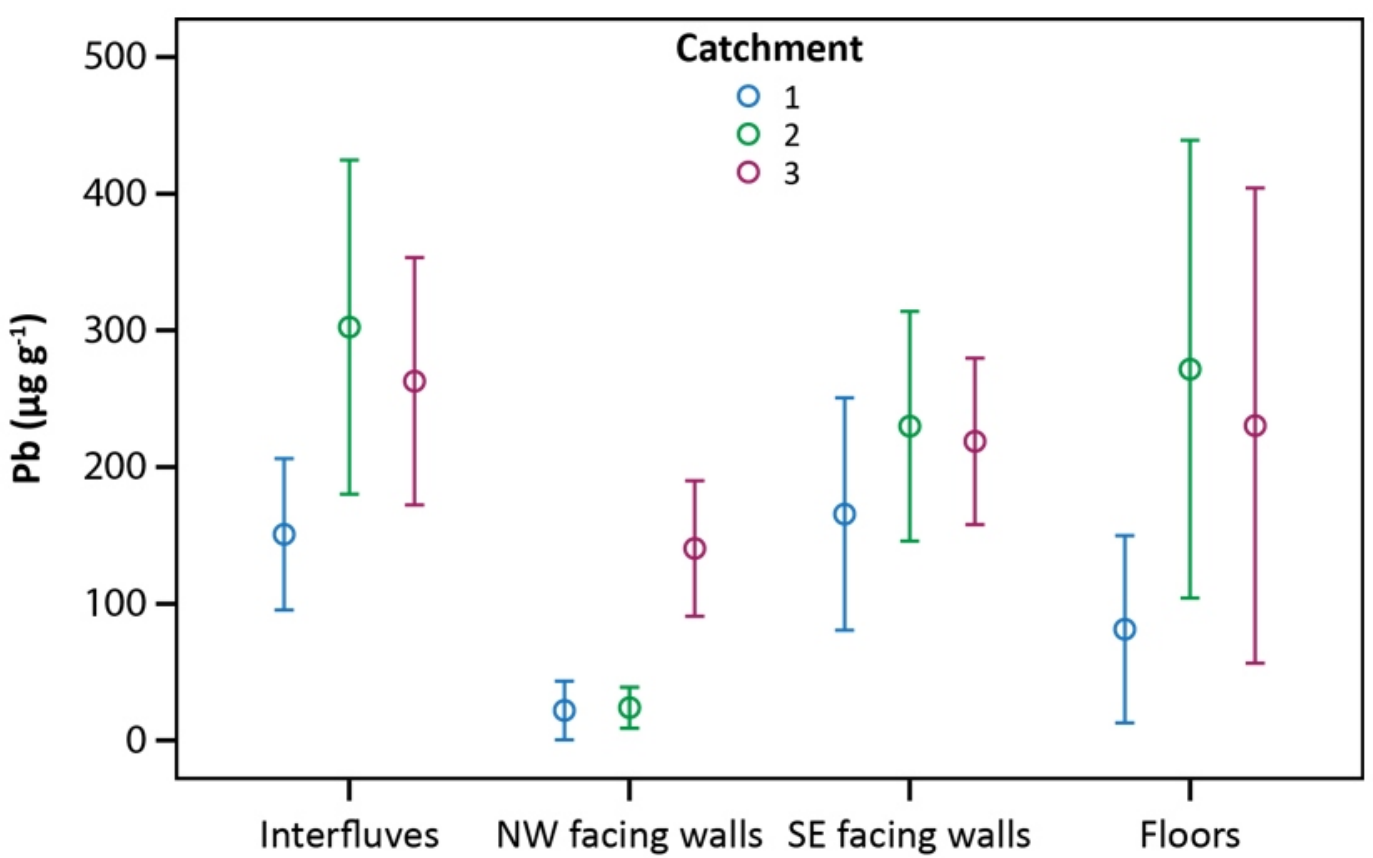




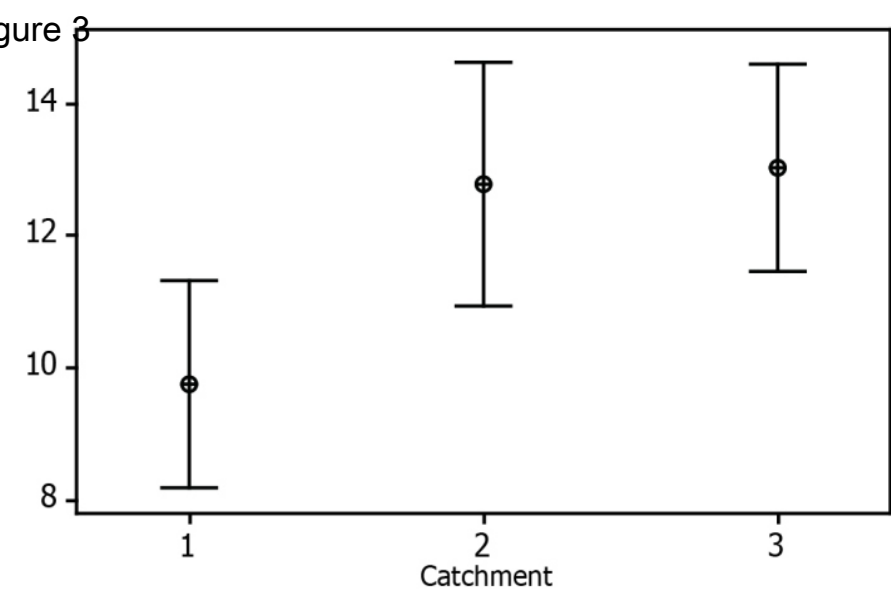

(b)

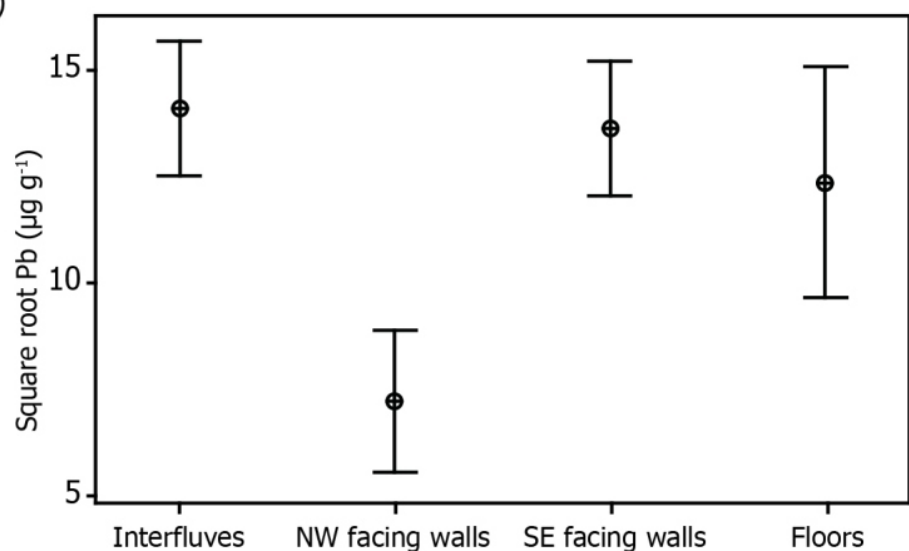

(c)

Surface Type

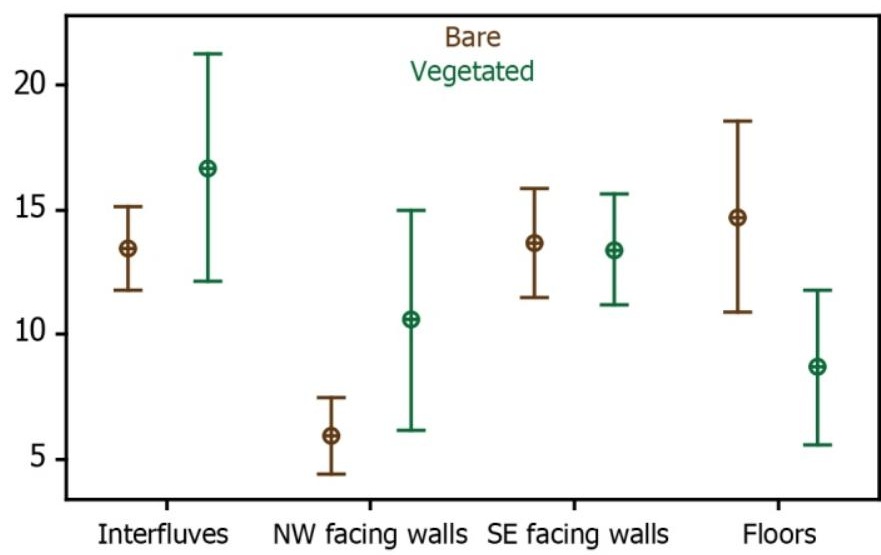

Surface Type 


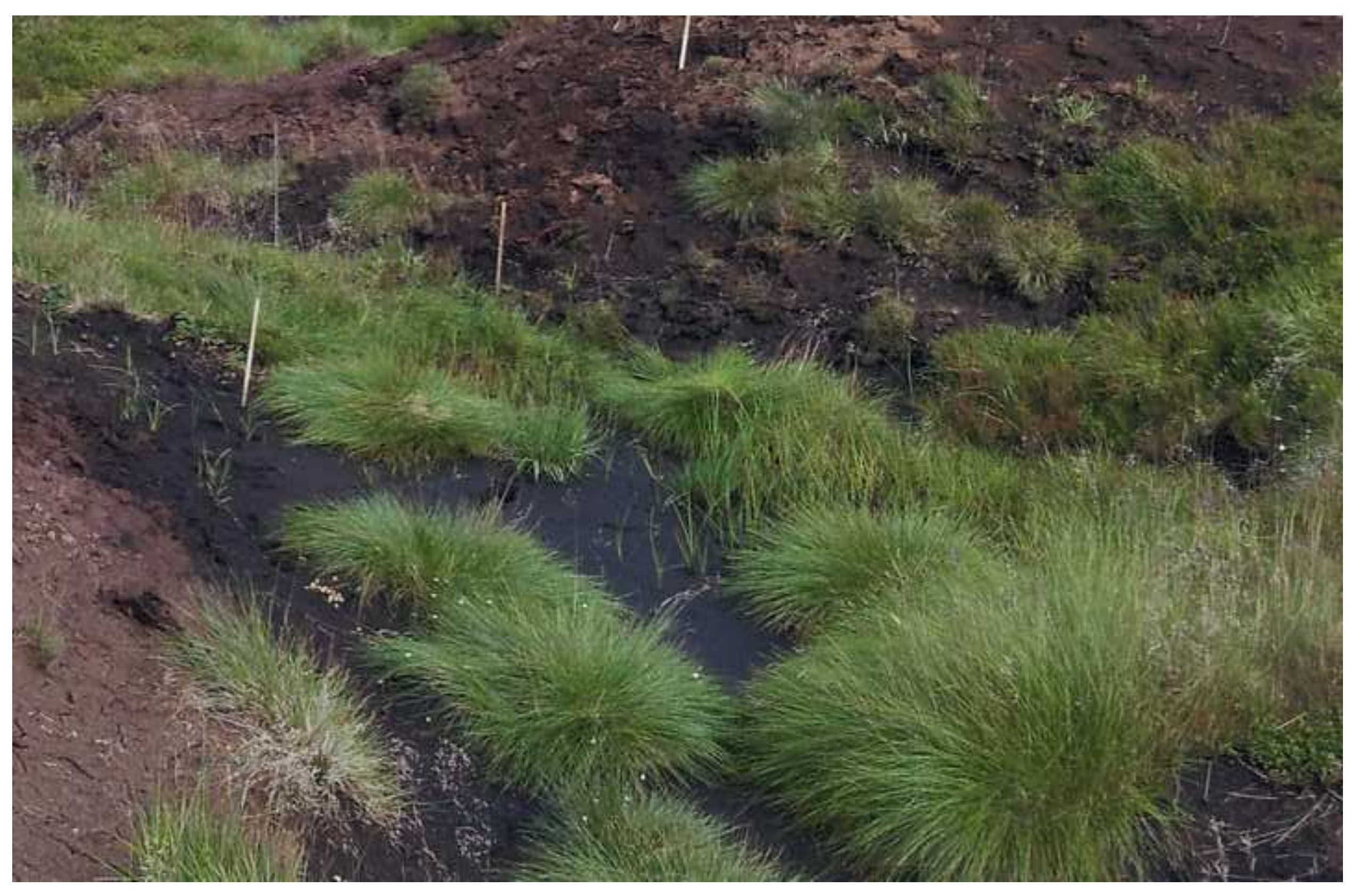


Table 1 Summary of selected controls on peatland sediment dynamics

\begin{tabular}{llll}
\hline Control & Mechanism & Effect & Study
\end{tabular}

Vegetation

Weathering

Erosion

Degree of degradation

$\begin{array}{ll}\text { Protects surface; } & \text { Reduces sediment } \\ \text { Traps mobilised } & \text { production; } \\ \text { sediment } & \text { Reduces sediment } \\ & \text { movement }\end{array}$

Frost

heave/needle ice;

Desiccation

Fluvial; Aeolian;

Mass movement
Prepares' surface;

Produces readily

mobilised sediment
Evans and Warburton (2005);

Shuttleworth et al. (2015)

.


Table 2 Descriptive statistics for $\mathrm{Pb}$ each factor tested by the GLM. LOD = limit of detection

\begin{tabular}{|c|c|c|c|c|c|c|}
\hline \multirow[t]{2}{*}{ Factor } & \multirow[t]{2}{*}{ Level } & \multirow[t]{2}{*}{$n$} & \multicolumn{4}{|c|}{$\mathrm{Pb}$ concentration $\left(\mu \mathrm{g} \mathrm{g}^{-1}\right)$} \\
\hline & & & Mean & R.S.D. & $\max$ & $\min$ \\
\hline \multirow[t]{3}{*}{ Catchment } & 1 & 48 & 124 & 95.7 & 502 & $<$ LOD \\
\hline & 2 & 69 & 222 & 116 & 1660 & $<$ LOD \\
\hline & 3 & 71 & 213 & 91.5 & 1010 & $<$ LOD \\
\hline \multirow[t]{4}{*}{ Surface type } & Interfluves & 75 & 245 & 81.3 & 1660 & $<$ LOD \\
\hline & NW-facing walls & 43 & 80.5 & 121 & 382 & $<$ LOD \\
\hline & SE-facing walls & 37 & 207 & 60.4 & 555 & $<$ LOD \\
\hline & Floors & 33 & 209 & 119 & 1010 & $<$ LOD \\
\hline \multirow[t]{2}{*}{ Vegetation cover } & Bare & 137 & 191 & 103 & 1010 & $<$ LOD \\
\hline & Vegetated & 51 & 200 & 120 & 1660 & $<$ LOD \\
\hline
\end{tabular}


Table 3 ANOVA results for square-root transformed data. $p=$ probability of factor being zero and $\omega^{2}=$ generalized proportion of variance explained. Significant results in bold

\begin{tabular}{lcc}
\hline Source & $p$ & $\omega^{2}$ \\
\hline Catchment & $\mathbf{0 . 0 1 5}$ & 0.033 \\
Surface & $\mathbf{0 . 0 0 0}$ & 0.172 \\
Vegetation cover & 0.642 & 0.000 \\
Catchment*Surface & 0.062 & 0.026 \\
Catchment*Vegetation cover & 0.227 & 0.002 \\
Surface*Vegetation cover & & \\
Total & $\mathbf{0 . 0 0 3}$ & 0.043 \\
& & \\
\hline
\end{tabular}


Table 4 Mean lead storage on bare and vegetated surfaces $\left(\mu \mathrm{g} \mathrm{g}^{-1}\right)$

Bare Vegetated

\begin{tabular}{lcc}
\hline All Surfaces & 191 & 200 \\
Interfluves & 223 & 338 \\
NW-facing & & \\
walls & 51.2 & 156 \\
SE-facing walls & 215 & 192 \\
Gully floors & 281 & 99.4 \\
\hline
\end{tabular}

